MARKETING AND BRANDING
RESEARCH $\begin{gathered}\text { INDUSTRIAL } \\ \text { MANAGEMENT } \\ \text { INSTITUTE }\end{gathered}$

\title{
Exchange development: Preparing the grounds for achievement of resistance economy
}

\author{
Negar Afkandeh \\ M. A. Student in Economy, Ahwaz Branch, Islamic Azad University, Ahwaz, Iran
}

\begin{abstract}
Keywords:

Resistive Economy, Securities, Bank-Based Economy, Market-Based Economy

Correspondence: negar.afkandeh@gmail.com

Some economic conditions in Iran such as presence of stagflation, inappropriateness of business environment, foreign investment decrease, and technological and technical knowledge disconnection of domestic product prepare a ground for activities in resistance economy field. Resistance economy prepares the grounds for the comprehensive growth and development even in the economic pressures and sanctions. Relying on the resistance economy, dependency on foreign countries should be reduced and increasing the self-reliance and the use of domestic products should be emphasized. Undoubtedly, stock market positively affects on manufacturing domestic products and reduces the market liquidity, since growth in manufacturing domestic products will reduce the country's dependence on some foreign goods and play pivot role in forming the proper consumption pattern in the resistance economy. Therefore, more companies will be established, product and national income will be increased and unemployment will be reduced. Currently, these effects are not obvious in the economy of the country, because the structure of Iran's financial system is seemingly bank-based not market-based. This descriptive-correlational study aims to investigate the impact of increase in stock market turnover on the disappearance of Iran's market-oriented economy which results in the formation of resistance economy. To this end, the statistics obtained of the World Bank and the International Monetary Fund (IMF) in 2006 and 2009 were used as statistical sample. The results revealed that the increase in Iran's stock market turnover emphasized on the vital role of private sector in expanding country's economy opportunities and prepared the grounds for achievement of resistance economy through increasing domestic product.
\end{abstract}

(C)AIMI Journals

\section{Introduction}

If Iran's economy passes its long-term stagflation crisis, it will encounter with economic sanctions, economic corruption, and it will re-enter the states of oil-dependent economy. To 
meet the economic needs of Iran, there are appropriate decision-making and policy-making models in the world. This new perspective on economic decision-making and policy-making which may improve and empower the poor conditions of Iran's ailing economy is called resistance economy. Resistance economy is formed based on internal capital and domestic product. Accordingly, stock market provides better condition for further encouraging production of domestic products and reducing market liquidity. In fact, the growth in manufacturing domestic products reduces the country's dependence on some foreign goods. One way to increase the production and sales of domestic products, reduce market liquidity and inflation, and accomplish the objectives of resistance economy is developing stock market in country.

Exchange has short-term and long-term impacts on the real sectors of countries' economy. Its short-term consequence is the increase in the production rate and its long-term consequences are controlling inflation, reducing unemployment, and entering money into the parallel markets which has no positive impact on the economy such as currency, coin, and housing.

Parallel markets do not have productive nature; however, if the capital is utilized for manufacturing domestic products, more companies will establish, product and national income will increase, and unemployment will reduce.

Unfortunately, these impacts are not particularly obvious in the economy of the country, because Iran's economy is bank-based not market-based. In bank-based systems banks play a leading role in mobilizing savings, allocating capital, overseeing the investment decisions of corporate managers, and providing risk management vehicles.

In bank-based economy, bank carries out the payment of worker's wages in return for receiving money from them and then lends the money to the product section and earns more profit than the others. If the bank is deleted, the depositor should be cooperated with the producer directly and thus there will be no need to mediator. So, the money will be at producers' disposal, and people will buy cheap goods. Therefore, there will be a marketbased economy instead of a bank-based economy.

Some economic analysts believe that stock market and securities in developing countries do not have positive impact on economic growth; however, securities market can have a deep and protracted impact on economic growth and development based on recent studies (Demirguc-Kunt \& Levine, 2001). These markets can provide short-term working capital for the units as well as long-term capital for profitable investments through collecting the liquidity from society. In addition to securities market, banks are considered as a major financial provider. In developing countries, the managers of companies are not aware of useful tools such as exchange; therefore, the needed working capital is provided through banking system. In fact, borrowing from banking system has deep inflationary reflections (Saeedi, \& Amiri, 2009).

This study tries to investigate the impact of stock market turnover increase on the disappearance of Iran's economy market which results in resistance economy. The results indicated that the increase in Iran's stock market turnover emphasized on the vital role of private sector in expanding country's economy opportunities and prepared the grounds for achievement of resistance economy through increasing domestic product. 


\section{The Review of Literature}

\section{Resistance Economy}

Iran's national economy in its current state encounters with particular conditions and events which can initiate the formation of a unique economic perspective in economy science whether in practice or theory in order to meet the needs of Iran's economy and present an appropriate model of decision-making and policy-making to the world.

Resistance economy as a dynamic and long-term economy consists of methods for lifting sanctions against an area or a country especially when export and import are not valid in that country or it is under pressure due to various economic limitations. Resistance economy prepares the ground for the growth and development even in economic pressures and sanctions. In order to expand resistance economy, dependence on foreign countries must be decreased and domestic product and also attempt to self-reliance must be emphasized (Khanbashi, 2012).

Dynamic resistance economy requires strategic planning based on democratizing economy through providing opportunity for the activists of private sectors and overcoming the obstacles and problems of this sector. The private sector as the main stimulus to industrial and economic development utilizes its capital resources, attracts and cooperates in nongovernment capitals, uses human resources to achieve the optimal output and does efficient management, plays a strategic role in the process of countries' industrial and economic development and accomplishes developing objectives of the government. Resistance economy is based on the spiritual capital of people and society and the private sector undoubtedly provides the best ground for accompanying people which is the most important aspect of resistance in the society and for directly or indirectly protecting the economy against sanctions.

\section{Securities}

Securities are an organized and official capital market in which the shares of companies, government bonds, and valid private institutions are transacted under special regulated rules. The main attributes of securities are the support of law from the legal owners of savings and dead capitals and legal requirements for those who demand the financial capital.

Since the companies of private sector and manufacturing firms play a significant role in developing the economy of each country, recognizing those factors which lead to their development is of great importance. The development of companies and business units depends more on financing support, investment, and business units need. Stock market and securities provide financial support and facilitate capital formation.

Some economic analysts believe that stock market and securities in developing countries do not have a positive impact on economic growth; however, stock market can have a profound impact on economic growth and development according to the recent studies. This market can provide short-term capital for units as well as long-term capital for profitable investments. In addition to securities market, banks also provide a wide range of important financial services. Due to the unawareness of companies' managers in developing countries of the usefulness of tools such as exchange, the needed capital is provided through bank 
system. In fact, borrowing money from banking system encourages deep reflections (Saeedi, \& Amiri, 2009).

Operating privatization policies in the framework of the principle 44 of the constitutional law and assigning public companies in exchange (which has been initiated in 2007) improved the capital market. Moreover, Securities and Exchange Organization has been committed in 2005 which had positive impacts on development of securities market in terms of protecting investors, promoting fair, orderly, and efficient markets, and facilitating capital formation from 2006 to 2009.

\section{Research Hypothesis}

The study specifically aimed to answer the following research hypothesis:

-Stock market turnover increase has a significant impact on the disappearance of Iran's market-oriented economy which results in the formation of resistance economy.

\section{Method}

The present study is a descriptive-correlational research that attempts to survey the statistics of World Bank and International Monetary Fund from 2006 to 2009 as statistical sample to answer the research hypothesis. The reason for selecting these years was the empirical investigation of the impacts of the capital market changes and assigning public companies in exchange as a result of privatization policies. Based on the findings of various studies investigating bank-based or market-based financial systems, different indicators have been used to study these two financial systems in their various possible dimensions which the composite indicator is the best one (Ebrahimi, 2014). The composite indicator was developed by Beck, Demirguc-Kunt, and Martinez Peria (2007) and it was used in other studies such as Levine's study (2002), has been used in this study as well. According to the literature, the more a system is market-based, the more the relative activity of capital market in proportion to the activity of bank will be. As a result, the relative size of capital market in proportion to the size of bank and the relative efficiency of capital market in proportion to the efficiency of bank will also increase. To provide a broad approach; therefore, this paper focuses on four indicators of financial structure based on measures of the relative activity, size, and efficiency of banks and markets. Structure-activity is a measure of the activity of stock markets relative to that of banks. This indicator equals the logarithm ${ }^{1}$ of the total value traded ratio divided by the facilities awarded by banks to the private sector. Larger values of structure-activity indicator imply a more market-based financial system. Structure-size is a measure of the size of stock markets relative to that of banks. This indicator equals the logarithm of the market capitalization ratio divided by the bank credit ratio. Structure-efficiency is a measure of the efficiency of stock markets relative to that of banks. To estimate the efficiency of stock markets, the logarithm of the total value traded ratio divided by the overhead costs of the banking system relative to banking system assets. Structure-aggregate is a conglomerate

\footnotetext{
${ }^{1}$ In order to homogenize the calculated data and achieving a better result, the logarithm of all the indicators have been calculated.
} 
measure of financial structure based on activity, size, and efficiency. Furthermore, this indicator is variable because it can explain the first three financial structure indicators.

\section{Results}

Table 1 presents four indicators of financial structure related to the ratio of capital market to the bank from 2006 to 2009 . These proportions were $-2.59,-0.79$, and -6.23 respectively and their negative numbers are due to their logarithms which indicate the different dimensions of bank-based economy in Iran. According to Table 1, bank-based economy is weaker in terms of relative markets' size and stronger in terms of their efficiency. According to the amount of structure-aggregate indicator which is -1.94, Iran's financial system is apparently highly bank-based and therefore is dependent on bank sources rather than on market. In 2009, the number of these indicators changed into $-2.09,-1.54$, and -5.15 respectively. The comparison between these numbers with the similar indicators in 2006 and 2009 revealed that there are some facts related to the number fluctuations of these indicators. As structure-activity indicator has increased, Iran's financial system is not considered as bank-based anymore and capital market has been used more actively from 2006 to 2009. As the indicator of structureactivity has increased, Iran's financial system is not considered bank-based anymore and capital market has acted more actively from 2006 to 2009. Thus, the stock market value traded is more than the facilities awarded by banks to the private sector. Iran's financial system is more bank-based during this period, since the structure-size indicator is smaller than the relative size of the capital market in proportion to banks. In other words, the size of banking sector in Iran is significantly greater than capital market from 2006 to 2009. Furthermore, as structure-efficiency indicator has increased, the efficiency of capital market in proportion to banks has increased from 2006 to 2009.

Table 1

The Four Indicators of Financial Structure Related to the Ratio of Capital Market to the Bank

\begin{tabular}{ccccc}
\hline $\begin{array}{c}\text { Structure-Activity } \\
\text { Indicator }\end{array}$ & Structure-Size Indicator & $\begin{array}{c}\text { Structure-Efficiency } \\
\text { Indicator }\end{array}$ & Structure-Aggregate Indicator & Year \\
\hline-2.59 & -0.76 & -6.23 & -1.94 & 2006 \\
-2.09 & -1.54 & -5.15 & -1.29 & 2009 \\
\hline
\end{tabular}

Table 2 summarizes the main indicators of the performance of Tehran Stock Exchange based on the statistics of World Bank in collaboration with the International Monetary Fund.

Table 2

The Main Indicators of the Performance of Tehran Stock Exchange

\begin{tabular}{lll}
\hline The Name of Indicator & 2009 & 2006 \\
\hline Iran's Stock Market Turnover & 30.71 & 12.95 \\
\hline
\end{tabular}

According to Table 2, the statistics of World Bank stated that Iran's stock market turnover were 12.95 and 30.71 per cent respectively in 2006 and 2009.

Although, the changes in Iran's financial structure are not considered market-based in terms of their size from 2006 to 2009, the focus of banking financial services is not reduced. 
Therefore, the Iranian capital market has become much more active and Iranian financial system has become more market-based in terms of structure-activity indicator. Moreover, in terms of efficiency, capital market showed better economic efficiency in proportion to banks and it can be concluded that Iranian financial structure has become more market-based. The size comparison of structure-aggregate in 2006 and 2009 reveals that this amount is greater than the structure-aggregate in 2006. Thus, it is concluded that Iranian financial system is not considered bank-based anymore in recent years and market capital has performed more in terms of activity, size and efficiency.

Furthermore, it is believed that after changing the rule of capital market and assigning exchange to public companies as a result of privatization policies which increased Iran's stock market turnover form 12.95 per cent to 30.71 per cent and indicated the significant rates of growth in trade value in proportion to market value, Iranian financial system has been transformed into a market-based system. In fact, this transformation is due to having more active and efficient markets than banks.

\section{Conclusion}

Resistance economy, the kind of lasting economic, is formed based on the internal capital and domestic product and undoubtedly, stock market provides the best ground for encouraging citizens to use domestic product and reducing liquidity. In fact, increased domestic production will reduce Iran's dependency on using some foreign goods. One of the strategies which can increase domestic production, reduce liquidity and inflation in the market, and achieve the goals of the resistance economy is stock market development in our country.

In the economy of each country, exchange rate has short-term and long-term effects. In the short-term effect, production increases while long-term effect controls inflation in the market, reduces the unemployment rate, and enters money into the parallel markets which have no positive impact on the economy such as currency, coin, and housing through improving manufacturing process. Parallel markets do not have productive nature. If the initial capital is used to manufacture domestic products, more companies will be established, product and national income will be increased, and unemployment will be reduced. If the exchange can find its proper position, its effect will be obvious in macroeconomics. Currently, these effects are not obvious in the economy of the country, because Iran's financial system has transmitted from market-based into the bank-based system. In bank-based payment system, banks pay people's wages instead of receiving money from them. Furthermore, they lend money to the purchasers of the manufacturing sections and make much profit. If banks are deleted, depositors would cooperate with producers directly without the presence of any mediator, money would be at producers' disposal and therefore people would buy cheap goods. Therefore, a market-based financial system will play the dominant role instead of a bank-based one. The findings of this research paper indicated that increase in Iran's stock market turnover from 2006 to 2009 led into the significant increase in total value traded in proportion to market value which has transformed Iran's bank-based financial system into a market-based. In recent years, assigning this system to the companies do not lead to any kind of changes in the size of capital markets, it has just reduced the access to the bank-based financial system, expanded the role of the private sector in country's economy, increased the 
growth rate of domestic product, and finally developed resistance economy through activating and improving the capital market efficiency.

\section{References}

Beck, T., Demirguc-Kunt, A., \& Martinez Peria, M. S. (2007). Reaching out: Access to and use of banking services across countries. Journal of Financial Economics, 85(1), 234- 266.

Demirguc-Kunt, A., \& Levine, R. (2001). Financial structures and economic growth: A cross-country comparison of banks, markets, and development. Cambridge, M.A.: MIT Press.

Ebrahimi, S. (2014). Structure of financial market in Iran: Bank-based or market-based. Quarterly Journal of Fiscal \& Economic Policies, 1(4), 25-44.

Khanbashi, M. (2012). Impact of economic factors on political trust. Rahbord, 20(61), 277-315.

Levine, R. (2002). Bank-based or market-based financial systems: Which is better? Journal of Financial Intermediation, 11(4), 398-428.

Saeidi, P., \& Amiri, A. (2009). Relation between macroeconomic variables and general index in Tehran Stock Exchange Market. Economic Modeling, 2, 111-130. 